\title{
Relationships between the Growth of Ethnic Groups and Socioeconomic Conditions in US Metropolitan Areas
}

\author{
ChiHyoung Park*
}

\begin{abstract}
Growth of the three largest US ethnic minorities (Hispanics, blacks, and Asians) is compared against three socioeconomic conditions-income, poverty, and employment-in US metropolitan statistical areas. The literature on the geography of ethnicity, particularly its social and economic findings, needed additional data collection and analysis. Findings from this research demonstrate that the social and economic characteristics of blacks, Hispanics, and Asians differed between central and suburban cities, and were more important descriptors and explanatory factors for socioeconomic changes in central cities than in suburban cities between 1990 and 2000. Growth among blacks and Hispanics, but not Asians, affected socioeconomic changes in those groups in central cities and suburban cities in U.S. metropolitan areas. These findings support the perception of overall improved socioeconomic status in these central and suburban cities for black and Hispanic growth.
\end{abstract}

Keywords: ethnic growth, socioeconomic conditions, central cities, suburban cities, US metropolitan statistical areas

\section{INTRODUCTION}

Understanding of urban issues assists local government policy decisions. Urban policy involves socioeconomic issues such as growth of urban ethnic minorities, population, poverty, employment, and income. Urban socioeconomic situations provide information for public administration and policies that focus on the urban crisis and what local government can do about it. This study explores current perspectives and practices in the analysis of the relation between the growth of ethnic minorities in urban areas and socioeconomic conditions_-and its implications for developing,

\footnotetext{
* ChiHyoung Park is an assistant professor in the Public Administration Department at Kongju National University. This work was supported by a research grant from Kongju National University in 2010. Email: chpark@kongju.ac.kr
}

Manuscript received June 8, 2011; out for review June 17, 2011; review completed July 13, 2011; accepted July 26, 2011.

The Korean Journal of Policy Studies, Vol. 26, No. 2 (2011), pp. 121-136.

(C) 2011 by the GSPA, Seoul National University 
implementing, and evaluating public programs for solving urban socioeconomic problems related to the growth of ethnic minorities.

This study examines the growth of ethnic minorities in central and suburban cities in US Metropolitan Statistical Areas (MSAs) since the 1990s, and provides a basis for anticipating the 2000-2010 conditions to be developed from the 2010 census. It focuses on two types of location: (1) 92 central cities within 92 MSAs with populations exceeding 500,000 (361 MSAs) ${ }^{1}$ and (2) 244 suburban cities out of 724 with populations exceeding 25,000 in the same MSAs. Metropolitan suburban minority populations grew from 18 percent in 1990 to 25 percent in 2000; black populations grew 38 percent and Asian and Hispanic populations grew 72 percent and 84 percent respectively in the metropolitan suburbs during the 1990s (Logan, 2001).

Hispanic and Asian immigrants have apparently continued to affect the growth of metropolitan areas in the recent past (Frey, 2001b, 2005); for example, the number of immigrants in central cities increased by 3.5 million, and immigrants in suburban cities increased by 4.8 million (Logan, 2003). Suburban cities became more heterogeneous in their ethnicity, while many central cities trended toward homogeneity, different from earlier trends (Galster \& Booza, 2007). For these reasons, there is a need to develop a comprehensive, large-scale data set to compare the growth of black, Hispanic, and Asian populations in central cities and their suburbs between 1990 and 2000 in US MSAs. Statistical associations of data from central cities and suburban cities should indicate that ethnic growth rates relate to three socioeconomic conditions: urban poverty rate changes, per capita income growth rates, and employment growth rates.

\section{LITERATURE REVIEW}

Race analysis is "the systematic application of the tools of historical and cultural analysis to understand the social and economic circumstances facing blacks and other racial minority group members" (Myers, 2002). It is used in many scholarly domains, but is largely absent from the field of policy analysis. Accordingly, many researchers could learn from the following discussion of policies that would have benefited from a better understanding of the effects of race and socioeconomic conditions such as income, poverty, and employment in US Metropolitan Statistical Areas (MSAs).

Land is being rapidly developed outward beyond central cities to accommodate population growth in different ethnic groups (Marshall, 2007) and the resultant socioe-

1. State and Metropolitan Data Book: 2006 by U.S. Census Bureau 
conomic challenges (Jennings, 2004; Frey, 2005; Pack, 2005). Unemployment, poverty, joblessness, and other social factors are not evenly distributed across metropolitan areas (Wilson, 1987; Abramson, 1995; Jarkowsky, 1997; Adelman \& Jaret, 1999; Stoll, Holzer, \& Ihlanfeldt, 2000; Dreier, Mollenkope, \& Swanstrom, 2001; Jennings, 2004; Frey, 2005; Pack, 2005; Mogull, 2007). Socioeconomic issues and differences are commonly stated for blacks and Hispanics living in metropolitan areas; for example, the unemployment rate of white adults was 3.3 percent in 1999, while blacks and Hispanics had unemployment rates of 8.1 and 5.8 percent respectively, according to the U.S. Bureau of Labor Statistics (Stoll, Holzer, \& Ihlanfeldt, 2000). The rise in joblessness adversely affected a growing number of poor, single-parent families in central cities and increased concentrations of both poverty and welfare dependency (Wilson, 1996; Fisher \& Monica, 2004).

According to Madden (2003), larger and older central cities in the Northeast and Midwest experienced increased poverty rates and decreased incomes relative to their own suburbs; that is, upper-middle-income groups moved to the suburbs between 1970 and 1990, while lower-income groups remained in the central cities. Dreier, Mollenkope, and Swanstrom (2001) argued that poverty and income explain economic conditions about urban ethnic groups' geographical shifts within MSAs.

Wilson $(1987,1996,2003)$ argued that these shifts related to social characteristics such as income and race. Accordingly, they were related to both the urban economy's affect on minorities and the stickiness resulting from being low wage earners in a labor force concentrated in areas of cities and suburbs. The shift in the national economy from goods-producing to service-producing industries increased the polarization of the labor market into low- and high-wage sectors, and the relocation of many manufacturing industries out of central cities has raised the joblessness rate there (Wilson, 1987, 2003; Jargowsky, 1997; Dreier, Mollenkopf, \& Swanstrom, 2001).

Ihlanfeldt (2004) argued that black and Hispanic low-income households are apt to live in different neighborhoods than whites, leading to persistent high levels of racial income segregation. Jargowsky (1996) revealed a steady trend toward economic segregation among racial and ethnic groups. Economic segregation repressed socialization and negatively affected racial integration in MSAs, harming most existing integrated areas in cities.

Economic inequality also significantly promoted economic segregation and reduced opportunities for minorities in metropolitan areas (Dreier, Mollenkope, \& Swanstrom 2001). Swanstrom, Dreier, Casey, and Flack (2006), sorting 1980s and 1990s households by income, uncovered wide and variable income gaps not only between cities and suburbs but also among different suburbs in the same MSA. They argued that economic segregation created geographic changes with varying impacts on 
a decline in the spatial concentration of poor households, growing suburbanization of poverty, and a steady loss of upper-income households in central cities over the past few decades.

Economic segregation makes it easier to isolate ethnic groups of similar economic backgrounds in the same legislative voting districts, making it difficult for them to participate with others in diverse community activities such as nothing and other forms of civic engagement in metropolitan areas (Judd \& Swanstrom, 2004). According to Jargowsky (1997), poverty rates for whites, blacks, and Hispanics in metropolitan areas were 7.5 percent, 26.4 percent, and 23.9 percent respectively, based on 1990 data. His study showed significant variations in poverty rates among the three ethnic groups. Minority ethnic groups such as blacks and Hispanics living in metropolitan areas did rise in number substantially compared to whites.

According to Franklin (2003), domestic migrants lead the largest population growth in fast-growing metropolitan areas such as Las Vegas, Riverside, and Raleigh; over 22 million people changed their places of residence between 1995 and 2000. Glaeser and Shapiro (2001) concluded that metropolitan areas with warm climates grew while others declined in population.

According to Frey (2001b), blacks migrated out of southern states yet have returned in recent decades. Frey reported that southern MSAs, such as Orlando and Atlanta, had the highest rates of black population growth between 1990 and 2000. Black migration contributed substantially to the growth rate in southern metropolitan areas in the 1990s and substantially improved the social and economic lives of both existing and newly arrived blacks.

Frey also noted that professional jobs increased and a larger black middle class emerged in Atlanta, Charlotte, and Dallas, as blacks moved into suburban cities in those same southern metropolitan areas. Vey and Forman (2006) argued that western and southern MSAs experienced rapid population growth including among racial and ethnic minorities, and satellite cities farther from the cores of metropolitan areas tended to grow faster than their central cities. That is, the suburban cities of metropolitan areas in southern and western regions absorbed domestic ethnic-minority migrants.

Immigrants also continued to drive the growth of ethnic minorities in metropolitan areas such as Los Angeles, Dallas-Fort Worth, and Washington, DC, which to a degree became immigration gateways (Frey, 2005; Katz \& Lang, 2006). Many large cities have considered or adopted ordinances that protect immigrants, including illegal immigrants (Jennings, 2004), ${ }^{2}$ even though the Immigration Reform and Immigrant

2. Political debates about immigration reform criticize this increase in MSA diversity by calling such cities "sanctuary cities." 
Responsibility Act requires local governments to cooperate with the Department of Homeland Security's Immigration and Customs Enforcement agency. "Sanctuary cities" continue to encourage ethnic and racial population diversity in community development on behalf of pro-growth policies (Jennings, 2004).

Frey (2005) argued that the growth of large metropolitan areas such as New York and Los Angeles continued to be dominated by immigrants between 2000 and 2004. For example, in metropolitan populations, foreign-born whites and blacks make up less than 5 percent and foreign-born Asians and Hispanics are 67.6 percent and 40.9 percent respectively (Logan, 2003). Immigrants from a number of countries in Asia, the Caribbean, and Latin America moved to United States; accordingly, a desire for economic well-being propelled immigrants to move to metropolitan areas during past decades (Judd \& Swanstrom, 2004).

Glazer (2000) stated that immigrants were more likely to be poor and to have higher levels of unemployment, lower education levels, and larger families than native-born families (Judd \& Swanstrom, 2004). Immigrants had lower median household incomes than native-born people in the same ethnic groups in the past decades. However, according to Logan (2003), Hispanics and Asians moving into the United States had similar median annual household incomes, and black immigrants had higher median annual household incomes than native-born blacks-for example, Hispanic, native-born $\$ 38,000$ vs. immigrant $\$ 37,200$; Asian, native-born $\$ 67,000$ vs. immigrant $\$ 62,500$; black, native-born $\$ 33,200$ vs. immigrant $\$ 42,000$. Frey $(2001 b, 2005)$ argued that suburban diversity had rapidly increased due to an immigrant influx into metropolitan areas; Hispanic and Asian immigrants moved directly into the suburban cities without first moving to the central cities.

In summary, immigrants and domestic migrants continue to propel the growth of ethnic minorities in many large MSAs. Suburban population growth surpassed central city population growth in the 1990s (Logan, 2003; Pack, 2005). Asians and Hispanic populations grew on average 84 percent and 72 percent and black populations grew 38 percent in US metropolitan suburban areas between 1990 and 2000 (Logan, 2001). In addition, many black people moved to southern MSAs. In these ways, major metropolitan areas were changed by the dynamics of growth among ethnic minorities in both the central and suburban cities (Cushing \& Zheng, 2000; Logan, 2001; Dreier, Mollenkope, \& Swanstrom, 2001; Frey, 2005). 


\section{METHODS, DATA, AND HYPOTHESES}

\section{Methods}

Multiple analysis of covariance (MANCOVA) can test the interaction effects of independent interval variables on multiple dependent interval variables. It involves more than one dependent variable and one or more independent variables (Stevens, 2002; Todman \& Dugard, 2007). MANCOVA supports the use of interval scale variables as covariates. This study employs MANCOVA because of consisting of multiple independent and dependent variables as covariates. Applying this model to the growth rates of the three largest ethnic minority groups (Hispanics, blacks, and Asians) is useful for comparing the three dependent variables (income growth rate, poverty rate, and employment growth rate).

Accordingly, MANCOVA is applied to examine how the population growth rate for these ethnic groups affected socioeconomic changes in central and suburban cities in US metropolitan areas.

\section{Data}

The three independent variables for this analysis are the rates of growth for blacks, Hispanics, and Asians. There are three dependent variables: per capita income growth rate, change in poverty rate, and rate of growth in employment. All data are measured between 1990 and 2000 for 92 central cities, selected from 92 MSAs with populations over 500,000, and 244 suburban cities randomly selected from 724 suburban cities with populations over 25,000 in the same MSAs.

Altogether there are 97 MSAs with over 500,000 people; this study excludes five (El Paso, McAllen, Salt Lake City, Spokane, and Boise) with Hispanic populations over 78 percent or white populations over 95 percent (Rusk, 2003, p. 51). This allows reasonable review of the effect of growth of ethnic minorities (independent variables) on socioeconomic factors (dependent variables).

Table 1. Variables

\begin{tabular}{l|l}
\hline Independent variables & Growth rates 1990-2000 among blacks, Hispanics, and Asians \\
\hline \multirow{3}{*}{ Dependent variables } & Per capita income growth rate 1990-2000 \\
\cline { 2 - 2 } & Poverty rate change 1990-2000 \\
\cline { 2 - 2 } & Employment growth rate 1990-2000 \\
\hline Data source & U.S. Census Bureau \\
\hline
\end{tabular}


Table 2 shows how the central cities chosen for this study are distributed across the United States.

Table 2. Distribution of Sample Central Cities

\begin{tabular}{|c|c|c|c|c|}
\hline Region & Population & Cities & Population & Cities \\
\hline West (13 states) & $22.8 \%$ & 22 & \multirow{2}{*}{$58.7 \%$} & \multirow{2}{*}{54} \\
\hline South (16 states) & $35.9 \%$ & 33 & & \\
\hline Midwest (12 states) & $19.6 \%$ & 18 & \multirow{2}{*}{$41.3 \%$} & \multirow{2}{*}{38} \\
\hline Northeast (9 states) & $21.7 \%$ & 20 & & \\
\hline Total & $100.0 \%$ & 92 & $100.0 \%$ & 92 \\
\hline
\end{tabular}

Table 3 shows the same information for the 244 suburban cities chosen for this study, as well as for the larger group of 724 suburban cities from which they were selected. Therefore, the 244 suburban cities can represent all 724 .

Table 3. Distribution of Sample Suburban Cities

\begin{tabular}{c|c|c|c|c|c|c}
\hline \multicolumn{1}{c|}{ Region } & \multicolumn{3}{|c|}{ Total in study area } & \multicolumn{3}{c}{ Chosen for study } \\
\hline & Population & Cities & Combined areas & Population & Cities & Combined areas \\
\hline West (13 states) & $34.1 \%$ & 247 & West/South: & $25.9 \%$ & 63 & West/South: \\
\cline { 1 - 2 } South (16 states) & $21.8 \%$ & 158 & $55.9 \%, 405$ & $26.6 \%$ & 65 & $52.5 \%, 128$ \\
\hline Midwest (12 states) & $29.4 \%$ & 213 & Midwest/Northeast: & $30.3 \%$ & 74 & Midwest/Northeast: \\
\cline { 1 - 2 } Northeast (9 states) & $14.7 \%$ & 106 & $44.1 \%, 319$ & $17.2 \%$ & 42 & $47.5 \%, 116$ \\
\hline Total & $100.0 \%$ & 724 & $100.0 \%, 724$ & $100.0 \%$ & 244 & $100.0 \%, 244$ \\
\hline
\end{tabular}

\section{Hypotheses}

The hypotheses for central and suburban cities are as follows.

Hypothesis 1: There will be statistical differences in the means of each dependent variable - per capita income growth rate, change in poverty rate, and employment growth rate—on the growth rates for blacks, Hispanics, and Asians for the 92 central cities.

Hypothesis 2: There will be statistical differences in the means of each dependent variable - change in poverty rate, and employment growth rate-on the growth rates for blacks, Hispanics, and Asians for the 244 suburban cities. 


\section{DATA ANALYSIS}

MANCOVA was carried out for 92 central cities and 244 suburban cities on the growth rate of each ethnic group between 1990 and 2000. The results are discussed below, first for the central cities and then for the suburban cities.

\section{Central Cities}

The MANCOVA summary statistics for the 92 central cities are shown in tables 4 to 7. Roy's Largest Root (Roy's LR) tests focus on the independents and their interactions, and whether each effect is significant. The Roy's LR value for blacks is $0.321, \mathrm{~F}$ $=5.391, \mathrm{p}=0.000$; the Roy's LR value for Hispanics is 1.221, $\mathrm{F}=20.507, \mathrm{p}=0.000$; and the Roy's LR value for Asians is $0.122, \mathrm{~F}=2.042, \mathrm{p}=0.081$. The effect for the 92 central cities indicates overall significant values for blacks' and Hispanics' growth rates, but not for Asians' growth rate, at the 0.05 significance level.

The omnibus F test is the first step in the MANCOVA analysis shown in table 4. The F test appears in the Corrected Model of the Tests of Between-Subjects Effects. It tests whether the model is significant for each dependent. As shown in table 4, each $\mathrm{F}$ value is statistically significant for each dependent. The $\mathrm{F}$ tests reject the null hypothesis that there is no difference in the means of each dependent variable for the different groups formed by the independent variables. That is, there are statistical differences in the means of each dependent variable - per capita income growth rate, change in poverty rate, and employment growth rate—on growth rates for blacks, Hispanics, and Asians.

Table 4. Tests of Between-Subjects Effects (Central Cities)

\begin{tabular}{l|c|c|r|r|c}
\hline \multicolumn{1}{c|}{ Dependent variable } & Sum of squares & df & Mean square & F & Sig. \\
\hline Rate of growth in per capita income & $5,550.480$ & 3 & $1,850.160$ & $22.232^{* * *}$ & 0.000 \\
\hline Change in poverty rate & 204.307 & 3 & 68.102 & $11.047^{* * *}$ & 0.000 \\
\hline Rate of growth in employment & $18,011.247$ & 3 & $6,003.749$ & $3.576^{* *}$ & 0.017 \\
\hline
\end{tabular}

Source: Corrected Model.

${ }^{*} \mathrm{P}<0.1$; ${ }^{* *} \mathrm{P}<0.05$; ${ }^{* * *} \mathrm{P}<0.01$

\section{Per Capita Income Growth Rate}

The MANCOVA summary statistics for per capita income growth rate are presented in table 5. It shows a statistically significant growth rate for blacks $-F(1,88)=18.376$, 
$\mathrm{p}=0.000$-and Hispanics $-\mathrm{F}(1,88)=55.083, \mathrm{p}=0.000$. Black and Hispanic growth rates are related to decreases in the per capita income growth rate in the 92 central cities as explained by the negative coefficients. The Asian growth rate is not statistically significant for the per capita income growth rate.

Table 5. MANCOVA Summary for Per Capita Income Growth Rate in 92 Central Cities

\begin{tabular}{l|r|r|r|r|r|c}
\hline \multicolumn{1}{c|}{ Source } & \multicolumn{1}{c|}{ SS } & df & \multicolumn{1}{c|}{ MS } & \multicolumn{1}{c|}{$\mathrm{B}^{\mathrm{a}}$} & $\mathrm{F}$ & Sig. \\
\hline Intercept & $63,363.330$ & 1 & $63,363.330$ & 56.702 & 761.375 & 0.000 \\
\hline Black growth rate & $1,529.276$ & 1 & $1,529.276$ & $-1.240^{* * *}$ & 18.376 & 0.000 \\
\hline Hispanic growth rate & $4,584.096$ & 1 & $4,584.096$ & $-2.077^{* * *}$ & 55.083 & 0.000 \\
\hline Asian growth rate & 111.052 & 1 & 111.052 & 1.053 & 1.334 & 0.251 \\
\hline Error & $7,323.557$ & 88 & 83.222 & & & \\
\hline Total & $209,857.500$ & 92 & & & & \\
\hline
\end{tabular}

a Parameter estimates B in General Linear Model

General Linear Model (MANCOVA)

Covariate: the rate of growth in black, Hispanic, and Asian populations

${ }^{*} \mathrm{P}<0.1$; ${ }^{* *} \mathrm{P}<0.05$; ${ }^{* *} \mathrm{P}<0.01$

\section{Poverty Rate Change}

The MANCOVA summary statistics for poverty rate change are presented in table 6 , which shows a statistically significant growth rate for blacks- $F(1,88)=9.495, p=$ 0.003 - and Hispanics - F $(1,88)=31.427, \mathrm{p}=0.000$. Black and Hispanic growth rates are related to the increase in the poverty rate, as explained by the positive coefficients. The Asian growth rate is not statistically significant for poverty rate change.

Table 6. MANCOVA Summary for Poverty Rate Change in 92 Central Cities

\begin{tabular}{l|r|r|r|r|r|c}
\hline \multicolumn{1}{c|}{ Source } & \multicolumn{1}{c|}{ SS } & df & MS & Ba & F & Sig. \\
\hline Intercept & 130.453 & 1 & 130.453 & -2.573 & 21.161 & 0.000 \\
\hline Black growth rate & 58.533 & 1 & 58.533 & $0.190^{* * *}$ & 9.495 & 0.003 \\
\hline Hispanic growth rate & 193.740 & 1 & 193.740 & $0.243^{* * *}$ & 31.427 & 0.000 \\
\hline Asian growth rate & 3.599 & 1 & 3.599 & 0.427 & 0.584 & 0.447 \\
\hline Error & 542.494 & 88 & 6.165 & & & \\
\hline Total & 747.686 & 92 & & & & \\
\hline
\end{tabular}

a Parameter estimates B in General Linear Model

General Linear Model (MANCOVA)

Covariate: the rate of growth in black, Hispanic, and Asian populations

${ }^{*} \mathrm{P}<0.1$; ${ }^{* *} \mathrm{P}<0.05 ;{ }^{* * *} \mathrm{P}<0.01$ 


\section{Employment Growth Rate}

The MANCOVA summary statistics for employment growth rate are presented in table 7 , which shows a statistically significant black growth rate-F $(1,88)=10.571$, $\mathrm{p}=0.002$. The black growth rate is related to the decrease in the employment growth rate as explained by the negative coefficient. Hispanic and Asian growth rates are not statistically significant for employment growth.

Table 7. MANCOVA Summary for Employment Growth Rate in 92 Central Cities

\begin{tabular}{l|r|r|r|r|r|c}
\hline \multicolumn{1}{c|}{ Source } & \multicolumn{1}{c|}{ SS } & df & \multicolumn{1}{c|}{ MS } & \multicolumn{1}{c|}{ Ba $^{\text {a }}$} & F & Sig. \\
\hline Intercept & $10,719.543$ & 1 & $10,719.543$ & 23.322 & 6.385 & 0.013 \\
\hline Black growth rate & $17,747.207$ & 1 & $17,747.207$ & $-1.406^{* *}$ & 10.571 & 0.002 \\
\hline Hispanic growth rate & $1,551.715$ & 1 & $1,551.715$ & -4.225 & 0.924 & 0.339 \\
\hline Asian growth rate & 198.093 & 1 & 198.093 & -1.208 & 0.118 & 0.732 \\
\hline Error & $147,742.275$ & 88 & $1,678.889$ & & & \\
\hline Total & $175,255.312$ & 92 & & & & \\
\hline
\end{tabular}

a Parameter Estimates B in General Linear Model

General Linear Model (MANCOVA)

Covariate: the rate of growth in black, Hispanic, and Asian populations

${ }^{*} \mathrm{P}<0.1$; ${ }^{*} \mathrm{P}<0.05$; ${ }^{* * *} \mathrm{P}<0.01$

\section{Suburban Cities}

The MANCOVA summary statistics for the 244 suburban cities are shown in tables 8 to 11 . Roy's LR value for blacks is $0.054, \mathrm{~F}=2.638, \mathrm{p}=0.024$; for Hispanics 0.473 , $\mathrm{F}=22.317, \mathrm{p}=0.000$; and for Asians 0.064, $\mathrm{F}=3.009, \mathrm{p}=0.012$. The Roy's LR tests for the 92 central cities indicate overall significant values for black, Hispanic, and Asian growth rates at the 0.05 significance level.

The omnibus F test is the first step as shown in table 8. The F test appears in the Corrected Model of the Tests of Between-Subjects Effects. F values are statistically significant for rate of growth in per capita income and for change in poverty rate, but not for rate of growth in employment. For rate of growth in per capita income and change in poverty rate, the $\mathrm{F}$ tests reject the null hypothesis that there is no difference in the means of each dependent variable for the different groups formed by the independent variables. That is, there are statistical differences in the means of each dependent variable-rate of growth in per capita income and change in poverty rate on growth rate for blacks, Hispanics, and Asians. However, the other $\mathrm{F}$ tests fail to reject the null hypothesis that there is no difference in the means of each dependent for the different 
groups formed by the independent variables. Accordingly, there are no statistical differences in the means of each dependent variable - rate of growth in employment on growth rate for blacks, Hispanics, and Asians.

Table 8. Tests of Between-Subjects Effects (Suburban Cities)

\begin{tabular}{l|c|c|c|c|c}
\hline \multicolumn{1}{c|}{ Dependent variable } & Sum of squares & df & Mean square & $\mathrm{F}$ & Sig. \\
\hline Rate of growth in per capita income & $13,485.979$ & 3 & $4,495.326$ & $32.216^{* * *}$ & 0.000 \\
\hline Change in poverty rate & 95.255 & 3 & 31.752 & $4.234^{* * *}$ & 0.006 \\
\hline Rate of growth in employment & $3,563.460$ & 3 & $1,187.820$ & 0.867 & 0.459 \\
\hline
\end{tabular}

Source: Corrected Model.

${ }^{*} \mathrm{P}<0.1$; ${ }^{* *} \mathrm{P}<0.05 ;{ }^{* *} \mathrm{P}<0.01$

\section{Per Capita Income Growth Rate}

The MANCOVA summary statistics for capita income growth rate are presented in table 9, which shows a statistically significant black growth rate, $\mathrm{F}(1,240)=11.729$, $\mathrm{p}=.001$, Hispanic growth rate, $\mathrm{F}(1,240)=83.508, \mathrm{p}=.000$, and Asian growth rate, $\mathrm{F}$ $(1,240)=3.498, \mathrm{p}=.061$. Black, Hispanic, and Asian growth rate are statistically significant to capita income growth rate in the 244 suburban cities; however, the growth rates of the three ethnic groups have affected the decreases of income growth rate in the 244 suburban cities as explained by the negative coefficients. That is, their growth rates relate to the decrease of capita income growth rate in the 244 suburban cities.

Table 9. MANCOVA Summary for Per Capita Income Growth Rate in 244 Suburban Cities

\begin{tabular}{l|r|r|r|c|c|c}
\hline \multicolumn{1}{c|}{ Source } & \multicolumn{1}{c|}{ SS } & df & \multicolumn{1}{c|}{ MS } & \multicolumn{1}{c|}{$\mathrm{B}^{\mathrm{a}}$} & $\mathrm{F}$ & Sig. \\
\hline Intercept & $245,863.009$ & 1 & $245,863.009$ & 54.193 & $1,762.016$ & 0.000 \\
\hline Black growth rate & $1,636.611$ & 1 & $1,636.611$ & $-0.645^{* * *}$ & 11.729 & 0.001 \\
\hline Hispanic growth rate & $11,652.247$ & 1 & $11,652.247$ & $-1.421^{* * *}$ & 83.508 & 0.000 \\
\hline Asian growth rate & 488.105 & 1 & 488.105 & $-0.522^{*}$ & 3.498 & 0.063 \\
\hline Error & $33,488.411$ & 240 & 139.535 & & & \\
\hline Total & $554,395.455$ & 244 & & & & \\
\hline
\end{tabular}

a Parameter estimates B in General Linear Model

General Linear Model (MANCOVA)

Covariate: the rate of growth in black, Hispanic, and Asian populations

${ }^{*} \mathrm{P}<0.1$; ${ }^{* *} \mathrm{P}<0.05$; ${ }^{* *} \mathrm{P}<0.01$ 


\section{Poverty Rate Change}

The MANCOVA summary statistics for poverty rate change are presented in table 10 , which shows statistically significant growth rates for blacks- $F(1,240)=2.881, \mathrm{p}$ $=0.091$-and Hispanics $-F(1,240)=9.579, \mathrm{p}=0.002$. Black and Hispanic growth rates relate to the increase of poverty rates. The Asian growth rate is not statistically significant for poverty rate change.

Table 10. MANCOVA Summary for Poverty Rate Change in 244 Suburban Cities

\begin{tabular}{l|c|c|c|c|c|c}
\hline \multicolumn{1}{c|}{ Source } & SS & df & MS & Ba $^{a}$ & F & Sig. \\
\hline Intercept & 0.032 & 1 & 0.032 & -0.019 & 0.004 & 0.948 \\
\hline Black growth rate & 21.607 & 1 & 21.607 & $0.074^{*}$ & 2.881 & 0.091 \\
\hline Hispanic growth rate & 71.835 & 1 & 71.835 & $0.112^{* * *}$ & 9.579 & 0.002 \\
\hline Asian growth rate & 8.200 & 1 & 8.200 & 0.068 & 1.093 & 0.297 \\
\hline Error & $1,799.783$ & 240 & 7.499 & & & \\
\hline Total & $2,033.239$ & 244 & & & & \\
\hline
\end{tabular}

a Parameter estimates $B$ in General Linear Model

General Linear Model (MANCOVA)

${ }^{*} \mathrm{P}<0.1$; ${ }^{* *} \mathrm{P}<0.05$; ${ }^{* * *} \mathrm{P}<0.01$

Covariate: the rate of growth in black, Hispanic, and Asian populations

\section{Employment Growth Rate}

The MANCOVA summary statistics for employment growth rate are presented in table 11. None of the independent variables were significant for the employment growth rate. Black, Hispanic, and Asian growth rates do not relate to overall employment growth in the 244 suburban cities.

Table 11. MANCOVA Summary for Employment Growth Rate in 244 Suburban Cities

\begin{tabular}{l|r|r|r|r|r|c}
\hline \multicolumn{1}{c|}{ Source } & \multicolumn{1}{c|}{ SS } & df & \multicolumn{1}{c|}{ MS } & \multicolumn{1}{c|}{ Ba $^{\text {a }}$} & \multicolumn{1}{c}{ F } & \multicolumn{1}{c}{ Sig. } \\
\hline Intercept & $53,256.932$ & 1 & $53,256.932$ & 25.222 & 38.867 & 0.000 \\
\hline Black growth rate & 42.516 & 1 & 42.516 & 0.104 & 0.031 & 0.860 \\
\hline Hispanic growth rate & $3,180.466$ & 1 & $3,180.466$ & -0.742 & 2.321 & 0.129 \\
\hline Asian growth rate & 869.454 & 1 & 869.454 & -0.696 & 0.635 & 0.426 \\
\hline Error & $328,859.740$ & 240 & $1,370.249$ & & & \\
\hline Total & $437,785.218$ & 244 & & & & \\
\hline
\end{tabular}

a Parameter estimates B in General Linear Model

General Linear Model (MANCOVA)

${ }^{*} \mathrm{P}<0.1$; ${ }^{* *} \mathrm{P}<0.05$; ${ }^{* * *} \mathrm{P}<0.01$

Covariate: the rate of growth in black, Hispanic, and Asian populations 


\section{CONCLUSION}

The Black growth rate is statistically significant for the 92 central cities in all dependent variables: poverty rate, per capita income growth rate, and employment growth rate. Blacks may well have moved out of central cities to obtain jobs, because the black growth rate affected the decreases in the overall rate of growth in employment as explained by the negative coefficients. The black growth rate also relates to decreases in the per capita income growth rate in the 92 central cities; that is, the black growth rate affected the increase in the poverty rate in those central cities. Accordingly, the black growth rate is statistically significant for socioeconomic changes in the black populations in the 92 central cities. Also, the black growth rate relates to the overall socioeconomic changes in the black populations of the 244 suburban cities, because the other variables, except for the employment growth rate, are statistically significant for those suburban cities. Black growth rate has still affected the decrease of per capita income growth rates and the increase of poverty rates for the 244 suburban cities.

The Hispanic growth rate is also significant for poverty rate change and income growth rate, but not for the employment growth rate, for the 92 central cities. The Hispanic growth rate has affected the income growth rate decrease and the poverty rate increase in the 92 central cities. For the 244 suburban cities, even though the Hispanic growth rate does not relate to the employment growth rate, income growth rate and poverty rate change are statistically significant. That is, Hispanic growth rate has also affected the income growth rate decrease and the poverty rate increase in the 244 suburban cities.

The Asian growth rate is not statistically significant for any of the three dependent variables in the 92 central cities. However, it is statistically significant to per capita income growth rate in the 244 suburban cities as explained by the negative coefficient. That is, the Asian growth rate has affected the decrease of the per capita income growth rate in the 244 suburban cities.

This study shows that the socioeconomic characteristics of blacks, Hispanics, and Asians differed between the 92 central cities and 244 suburban cities in the 92 MSAs. The results have been more important descriptors and explanatory factors for socioeconomic changes in the central cities than in the suburban cities between 1990 and 2000. Black and Hispanic growth rates, but not Asian growth rates, strongly affect socioeconomic changes in the central cities rather than those in the suburban cities.

The overall characteristics of growth of ethnic minorities affect socioeconomic conditions in suburban areas in the United States. This study has endeavored to con- 
tribute to understanding of the relationships between the growth of ethnic minority populations and socioeconomic conditions in US cities. Information about the overall ethnic characteristics of cities can guide policy makers in local governments on what factors to consider and when to initiate rules to improve local socioeconomic conditions. This research reinforces the significance of local decision makers' understanding of the overall ethnic characteristics of their jurisdictions.

\section{REFERENCES}

Abramson, A. J., \& Tohin, M. S. 1995. The changing geography of metropolitan opportunity: The segregation of the poor in U.S. metropolitan areas, 1970 to 1990. Housing Policy Debate, 6: 45-72.

Adelman, R. M., \& Jaret, C. 1999. Poverty, race, and US metropolitan social and economic structure. Journal of Urban Affairs, 21: 35-57.

Cushing, B., \& Zheng, B. 2000. Reevaluating differences in poverty among central city, suburban, and non-metropolitan areas of the US. Applied Economics, 32: 653-660.

Dreier, P., Mollenkope, J., \& Swanstrom, T. 2001. Place matters: Metropolitics for the twenty century. Lawrence: University of Kansas Press.

Fisher, M., \& Weber, B. A. 2004. Does economic vulnerability depend on place of residence? Asset poverty across metropolitan and nonmetropolitan areas. Review of Regional Studies, 34: 137-155.

Franklin, R. S. 2003. Domestic migration across regions, divisions, and states: 1995 to 2000. Washington, DC: U.S. Census Bureau.

Frey, W. H. 2001a. Melting pot suburbs: A Census 2000 study of suburban diversity. Washington, DC: Brookings Institution Press.

. 2001b. Census 2000 shows large black return to the South, reinforcing the region's "white-black" demographic profile. Ann Arbor, MI: University of Michigan.

2005. Metro American in the new century: Metropolitan and central city demographic shifts since 2000. Washington, DC: The Brookings Institution.

Galster, G., \& Booza, J. 2007. The rise of the bipolar neighborhood. Journal of the American Planning Association, 73: 421-435.

Glaeser, E. L., \& Shapiro, J. 2001. Is there a new urbanism? The growth of U.S. cities in the 1990s. Cambridge, MA: Harvard University.

Glazer, N. 2000. On beyond the melting pot, 35 years after. International Migration Review, 34: 270-285. 
Ihlanfeldt, K. R. 2004. Introduction: Exclusionary land-use regulations. Urban Studies, 41: 255-259.

Jargowsky, P. A. 1996. Take the money and run: Economic segregation in U.S. metropolitan areas. American Sociological Review, 61: 984-998. 1997. Poverty and place: Ghettos, barrios, and the American city. New York: Russell Sage.

Jennings, J. 2004. Race, politics, and community development in U.S. cities. NY: SAGE Publications.

Judd, D. R., \& Swanstrom, T. 2004. City politics: Private power and public policy. New York: Pearson Education.

Logan, J. 2001. The new ethnic enclave in America's suburbs. Albany, NY: Lewis Mumford Center for Comparative Urban and Regional Research. 2003. America's newcomers. Albany, NY: Lewis Mumford Center for Comparative Urban and Regional Research.

Madden, J. F. 2003. The changing spatial concentration of income and poverty among suburbs of large US metropolitan areas. Urban Studies, 40: 481-503.

Marshall, J. D. 2007. Urban land area and population growth: A new scaling relationship for metropolitan expansion. Urban Studies, 44: 1889-1904.

Mogull, R. G. 2007. Metropolitan poverty: The case of Chicago. Journal of SocioEconomics 36: 619-629.

Myers, S. Jr. 2002. Presidential address - analysis of race as policy analysis. Journal of Policy Analysis and Management, 21(2): 169-190.

Pack, J. R. 2005. Sunbelt/frostbelt. Washington, DC: Brookings Institution Press.

Stevens, J. P. 2002. Applied multivariate statistics for the social sciences. Mahwah, NJ: Lawrence Erlbaum.

Stoll, M. A., Holzer, H. J., \& Ihlanfeldt, K. R. 2000. Within cities and suburbs: Racial residential concentration and the spatial distribution of employment opportunities across sub-metropolitan areas. Journal of Policy Analysis and Management, 19: 207-231.

Swanstrom, T., Dreier, P., Casey, C., \& Flack, R. 2006. Pulling apart: Economic segregation in suburbs and central cities in major metropolitan areas, 1980-2000. In A. Berube, B. Katz, \& R. Lang (eds.), Redefining urban and suburban America: Evidence from Census 2000. Washington, DC: Brookings Institution Press.

Todman, J., \& Dugard, P. 2007. Approaching multivariate analysis: An introduction for psychology. NY: Psychology Press.

Vey, J., \& Forman, B. 2006. Demographic change in medium-sized cities. In A. Berube, B. Katz, \& R. Lang (eds.), Redefining urban and suburban America: Evidence from Census 2000. Washington, DC: Brookings Institution Press. 
136 Relationships between the Growth of Ethnic Groups and Socioeconomic Conditions in US Metropolitan Areas

Wilson, W. J. 1987. The truly disadvantaged: The inner city, the underclass, and public policy. Chicago: University of Chicago Press.

. 1996. When work disappears: The world of the new urban poor. New York: Vintage.

2003. Race, class and urban poverty: A rejoinder. Ethnic and Racial Studies, 26: $1096-1114$. 